\section{Nastamonu Eğitim Dergisi Kastamonu Education Journal}

Kasım 2019 Cilt:27 Sayı:6

kefdergi.kastamonu.edu.tr
Başvuru Tarihi/Received: 16.01 .2019

Kabul Tarihi/Accepted: 01.04.2019

DOI: $10.24106 /$ kefdergi.3532

\title{
Okul Öncesi Öğretmen Adaylarının Fiziksel Aktiviteye Katılımlarını Etkileyen Faktörler
}

\section{Factors Influencing Pre-service Teachers' Physical Activity Participation}

Öz

\author{
Serap SEVIMLi-ÇELiK' ${ }^{1}$, Tuğçe Esra TERZioĞLU²
}

Öğretmenlerin fiziksel becerilerindeki yetkinlikleri etkileyen faktörlerin ele alınması ve bu faktörlerin derinlemesine incelenmesi, erken çocukluk döneminde gerekli olan günlük hareket ihtiyacının karşılanmasında önemli bir yere sahip olan öğretmenlerin fiziksel aktiviteye karşı tutumlarının belirlenmesinde önem taşımaktadır. Bu çalışma ile Beden Eğitim ve Oyun dersine katılan okul öncesi öğretmen adaylarının ( $n=28)$ fiziksel aktiviteye katılımlarını etkileyen faktörlerin belirlenmesi amaçlanmıştır. Ayrıca, bu faktörlerin öğretmen olduklarında sınıflarında fiziksel aktivite uygulamalarına ne derece etkisi olabileceğine yönelik tutumları da incelenmiştir. Çalışmada, katılımcıların bireysel hikayelerini içeren otobiyografik anlatım yöntemi kullanılarak, öğretmen adaylarının anlatımlarından doğrudan alıntılar yapılmıştı. Araştırma bulguları, fiziksel aktiviteye katılımda aile ve sosyal çevre ile çevresel faktörlerin önemli bir rol oynadığını ve bu deneyimlerin ileriki öğretmenlik uygulamalarına da yansıyabileceğini ortaya koymuştur. Bu bulgular neticesinde, fiziksel aktiviteye katılımda bu faktörlerin etkisi tartşılarak çözüm önerileri sunulmuştur.

Anahtar Kelimeler: fiziksel aktiviteye katlım, okul öncesi, öğretmen adayları

\section{Abstract}

In meeting the daily movement needs in early years, it is important to consider the factors that affect the competencies of teachers' physical skills and examine the effects of those factors on teacher's attitudes which could be detrimental for their future teaching practices. The study aimed to investigate the factors critical for pre-service teacher's participation to physical activities. Additionally, the study aimed to examine the effects of those factors on pre-service teacher's future physical activity practices in their classrooms. Twenty-eight pre-service teachers who registered to the Physical Education and Games course were participated in the study. The data was collected through autobiographical narratives which includes the individual stories of each participant regarding their physical activity participation. The findings of the study indicated that family and social environment and environmental factors play an important role for participation of physical activities and they can be critical in shaping the future teaching practices of pre-service teachers. The effects of those factors were discussed in depth and some suggestions were given.

Keywords: early childhood, physical activity participation, pre-service teachers 


\section{Extended Abstract}

Introduction: Investigating the factors that influence pre-service teachers' physical activity participation and the impact of those factors on their later physical participation and their future classroom practices play an important role in supporting children's physical activity participation as well. A variety of study results indicated that when teachers value physical activity participation, they are more likely to support it in their classrooms and to encourage children going outside and play with them (Brady, Gibb, Henshall, \& Lewis, 2008; Cashmore \& Sandra, 2008; Huang, Sallis, \& Patrick, 2009; Temple \& Naylor, 2010). Additionally, teachers who have high levels of self-efficacy regarding physical activity participation provide more energy and resources for children to be active both inside and outside of the classroom. However, teachers who have low self-efficacy levels or negative attitude toward physical activity indicated their hesitancy to support it in their classrooms (Copeland, Sherman, Kendeigh, Saelens, \& Kalkwarf, 2012). Addressing the factors that affect teachers' physical activity participation and examining those factors in depth will shed light on the problems that arise in supporting the daily physical activity needs of young children in early childhood settings.

Purpose of the Study: The study aimed to investigate the factors that affect the physical activity participation of pre-service teachers and the effects of those factors on their future classroom practices.

Method: In the study, autobiographical narrative method including individual stories of the participants was used. Through this method, it is aimed to get a deeper insight on participants' physical activity experiences and to examine how those experiences shape their future plans (Alan, 2016). The research was carried out with pre-service teachers who enrolled in the Physical Education and Games course. Through purposive sampling, 28 pre-service teachers between the ages of 20-27 years old participated to the study. All participants were informed about the purpose and the process of the study. In data collection, participants were asked to write autobiographical narratives regarding the factors affecting their participation to physical activities. Participants were also asked to write how those factors would shape their future teaching practices.

Conclusion and Recommendations: The study results indicated that parental and social support and environmental factors play critical role on pre-service teacher's physical activity participation. Moreover, the participants emphasized the effects of those factors on their future teaching practices. While support from family members affected the pre-service teacher's physical activity participation positively, little or no support affected their participation negatively. Similarly, teacher encouragement was another factor for pre-service teachers for physical activity participation. However, the majority of the participants recalled negative experiences from their previous physical education classes. Additionally, the participants mentioned limited opportunities regarding the sports facilities both in and outside of the school and in the neighborhood. It is necessary to be cognizant about all these factors that affect individual's participation to physical activity. First of all, parents need to be aware of their role on children's physical activity participation. Through seminars or interactive workshops targeted to parents, it is critical to discuss the powerful impact of parental support in adopting healthy and active lifestyles. In addition to the parental factors, the impact of a physical education teacher and the content of physical education classes need to be examined closely. Rather than having teacher-directed, product-oriented and competition-based classes, teachers would offer more child-centered, process-oriented, and collaboration-focused classes. In this way, individuals would recognize physical activity participation as a life-long habit. Finally, schools need to make their physical infrastructures to accommodate physical activity participation. While designing the school buildings or classrooms, active designs should be considered to make physical activity as a regular part of the daily schedule. Considering the aforementioned factors, it is necessary for policy makers, school administrators, teachers, and parents to consider their critical roles in supporting physical activity participation which have a strong effect on the future teaching practices of young children. 


\section{Giriş}

Günümüz çocukları her geçen gün daha fazla bilgisayar, tablet ve akıllı telefonlara maruz kalarak yaşamlarında büyük bir öneme sahip olan erken çocukluk dönemini hareketsiz olarak geçirmektedirler. Oysaki yaşamın temeli olan hareket, psikomotor becerileri geliştirmekle kalmayıp, beden ve alan farkındalığı gibi algısal becerileri kazandırarak ileriki yaşlarda aktif bir yaşam tarzının benimsenmesinde etkili rol oynamaktadır. 0-6 yaş grubunu kapsayan erken çocukluk döneminin özellikle 3-6 yaş aralığı temel hareket becerileri dönemi olarak bilinmekte ve bu beceriler üç ana başlık altında incelenmektedir. Örneğin, vücudun bir noktadan diğerine taşınması olarak tanımlanan yer değiştirme hareketlerinde çocuk, yürüme, koşma, atlama, sıçrama, yuvarlanma ve tırmanma gibi becerileri test ederken; hareket ederken ya da olduğu yerde vücut dengesini sağlamaya çalıştğı dengeleme hareketlerinde ise eğilme, esnetme, salınma, ağırlık aktarma, itme ve çekme gibi becerileri kazanır. Çocuğun herhangi bir nesneyi (örneğin top) kontrol ederken hareketi sürdürebilmesi olarak tanımlanan nesne kontrolü gerektiren hareketlerde ise atma, tutma, vurma, yuvarlama ve durdurma gibi beceriler gelişmektedir. Gallahue ve Ozmun (1998), kurallı oyunların, sporun ve dans aktivitelerinin yukarıda bahsedilen temel hareket becerilerinin kombinasyonlarını içeren daha karmaşık ve uzmanlaşmış becerilerden oluştuğuna vurgu yaparak, erken yaşlarda kazanılan temel hareket becerilerinin çocuğun ileriki yaşlarda daha karmaşık beceriler içeren etkinliklerine katımasına olumlu yönde etkisinin olacağını belirtmektedir. Örneğin, iyi kazanılmış atma, tutma ve sıçrama becerileri ileriki yaşlarda çocuğun basketbolda, teniste ya da voleybolda başarılı olmasında etkili olabilmektedir.

Yer değiştirme, dengeleme ve nesne kontrolü gerektiren fiziksel becerilerin gelişmesinde herhangi bir eğitime ihtiyaç duyulmaksızın doğal olarak geliştiği de iddia edilmektedir ve bunun sonucunda fiziksel gelişim, bilişsel ve duygusal gelişim alanları kadar hak ettiği ilgiyi görememektedir (Ignico, 1994; Stork \& Sanders, 2008). Ayrıca, erken çocukluk döneminden itibaren bilişsel becerilerin gelişiminin önemine yapılan vurgu, özellikle fiziksel gelişimin arka planda kalmasına sebep olmaktadır. Oysaki, tüm gelişim alanları için yapı taşlarının şekillendirildiği bu dönemde çocuğu fiziksel, bilişsel ve sosyal-duygusal alanlarda eşit olarak desteklemek gerekmektedir (Gabbard, 2000). Yapılan araştrrmalar göstermiştir ki birlikte desteklendiğinde hareket, problem çözme ve yaratıcı düşünme becerilerinden sorumlu frontal korteksin gelişmesini sağlayarak öğrenmeyi olumlu yönde desteklemektedir (Graham vd., 2002; Sibley \& Etnier, 2003).

Okul öncesi eğitim kurumları, fiziksel becerilerin geliştirilmesinde ve aktif bir yaşam tarzının benimsenmesinde belirleyici bir öneme sahiptir. Hareketi destekleyici çevre unsurlarına sahip okul ortamlarında bulunan çocukların, daha az destekleyici çevresel unsurlara sahip okul ortamlarında bulunan akranlarına kıyasla, fiziksel aktiviteye kathlımlarının daha yüksek ve gün içinde daha aktif oldukları gözlemlenmiştir (Bower vd., 2008; Dowda vd., 2009). Williams, Jean-Carter, Kibbe ve Dennison (2009), fiziksel aktivite düzeyini arttırmak amacıyla geliştirdikleri beden eğitimi programı kapsamında 3-5 yaş grubu çocuklar ile yaptıkları 10 dakika süren günlük yürüyüşlerin ve dans etkinliklerinin çocukların büyük kas gelişimlerini olumlu yönde etkilediğini gözlemlemiştir. Ayrıca, Dowda vd. (2009) çocukların taşınabilir oyun ekipmanları bulunan okulların oyun alanlarında, sabit oyun ekipmanlarına sahip olanlara kıyasla daha aktif olduklarını gözlemişlerdir.

Okulun çevresel unsurlarına ek olarak, öğretmen düşünce ve tutumlarının da çocukların erken yaşlarda hareket becerilerinin desteklenmesinde, çocukların fiziksel aktiviteye katılmasında ve yaşam boyu aktif bir yaşam tarzının benimsenmesinde önemli bir rol oynamaktadır. Yapılan araştırmalar fiziksel aktiviteye önem veren öğretmenlerin sınıflarında harekete daha fazla yer verdiklerini ve çocukların açık havada oynamaları yönünde destekleyici olduklarını bulmuştur (Brady, Gibb, Henshall, \& Lewis, 2008; Cashmore \& Sandra, 2008; Huang, Sallis, \& Patrick, 2009; Temple \& Naylor, 2010). Ayrıca, öğretmenlerin hareket becerilerinin gelişimi ile ilgili inanç ve değer yargılarının yanı sıra, konu hakkındaki bilgi ve fiziksel öz-yeterlikleri de önemli rol oynamaktadır. Çevresel unsurları aynı olan bir okul öncesi eğitim kurumunda bile öğretmenin tutumuna göre çocuklar çok farklı fiziksel ve açık hava deneyimleri yaşayabilmektedir. Örneğin, bir sınıfta öğretmen düşük fiziksel becerilerinden dolayı çocukların günlük hareket ihtiyaçlarını yeteri kadar destekleyemezken, fiziksel becerileri yüksek ve aktif bir öğretmen çocukları dışarı çıkmaları konusunda motive edip, çocukların oyunlarına katlarak aktif bir rol model oluşturabilir (Copeland, Sherman, Kendeigh, Saelens, \& Kalkwarf, 2012). Bu sebeple, öğretmenlerin fiziksel becerilerindeki yetkinlikleri etkileyen faktörlerin ele alınması ve bu faktörlerin derinlemesine incelenmesi, erken çocukluk döneminde gerekli olan günlük hareket ihtiyacının karşılanmasında ortaya çıkan problemlere ışık tutacaktır. Bu çalışma ile Beden Eğitim ve Oyun dersine katılan 28 öğretmen adayının fiziksel aktiviteye katılımlarını etkileyen faktörlerin belirlenmesi amaçlanmıştır. Ayrıca, bu faktörlerin öğretmen olduklarında sınıflarında fiziksel aktivite uygulamalarına ne derece etkisi olabileceğine yönelik tutumları da incelenmiştir.

\section{Yöntem}

Bu çalıșmada nitel araștırma yöntemlerinden olan katılımcıların bireysel hikayelerini içeren otobiyografik anlatım | Kastamonu Eğitim Dergisi, 27(6), 2019| 
yöntemi kullanılmıştır. Bu yöntem ile, katılımcıların konu ile ilgili geçmiş yaşantılarının yanı sıra bu yaşantıların mevcut öğretmenlik uygulamalarını nasıl etkilediğinin ve gelecek planlarını nasıl şekillendirebileceğinin (Alan, 2016) derinlemesine incelenmesi amaçlanmıştır.

\section{Katilımcılar}

Araştırma, Okul Öncesi Eğitimi Bölümü 2. sınıfinda zorunlu olan Beden Eğitimi ve Oyun dersini alan 28 öğretmen adayının çalışmaya gönüllü katılımı ile yapılmıştır. Fiziksel aktivite katılımlarına bakılmaksızın kolay ulaşılabilir durum örneklemesi yöntemi ile seçilen 28 katılımcıdan 28 'i de kadın olup, 20-27 yaş aralığındadır. Çalışmanın amacı ve süreci hakkında bilgilendirilen bütün katılımcılar, çalışmaya gönüllü katılım formunu imzalayarak araştırmacılara teslim etmişlerdir.

\section{Verilerin toplanması}

Verilerin toplanmasında katılımcıların fiziksel aktiviteye katılımlarını etkileyen faktörlerden bahsettikleri bireysel hikayelerini içeren otobiyografik anlatım yapmaları istenmiştir. Her biri en az 3 sayfa uzunluğunda olan anlatımlarında, katılımcılardan ailesel faktörlerden çevresel faktörlere kadar fiziksel aktiveye katılımlarını etkileyen faktörlerden ayrıntılı bir şekilde bahsetmeleri istenmiştir. Ayrıca, katılımcılardan bu faktörlerin gelecekteki öğretmenlik uygulamalarını nasıl şekillendirebileceğinden de bahsetmeleri istenmiştir.

\section{Verilerin analizi}

Çalışmadan elde edilen verilerin analizinde betimsel analiz yöntemi kullanılmıştır. Katılımcıların fiziksel aktiviteye katılımlarında etkili olan faktörlerin neler olduğu sorusunun yanıtının arandığı çalışmada, betimsel analiz yöntemi ile katılımcıların otobiyografik anlatımlarında araştırma problemine ilişkin olarak neler söylediklerinin ön plana çıkarılması amaçlanmıştır (Yıldırım \& Şimşek, 2008).

\section{Bulgular}

Öğretmen adaylarının fiziksel aktiviteye katılımlarında etkili olan faktörlerin neler olduğu sorusunun yanıtının arandığı çalışmada, bulgular iki ana başık altında sunulacaktır. Aile ve sosyal çevre faktörleri ile çevresel faktörlerin fiziksel aktiviteye katılımlarına etkileri, öğretmen adaylarının bireysel hikayelerini içeren otobiyografik anlatımlarından doğrudan alıntılar yapılarak örneklendirilecektir.

\section{Aile ve sosyal çevre faktörlerinin fiziksel aktivite katılımına etkisi}

Öğretmen adaylarının otobiyografik anlatımlarında aile, öğretmen ve arkadaş faktörlerinin fiziksel aktivite katılımına etkisi hem olumlu ve hem de olumsuz olarak dile getirilmiştir. Katılımcı 28 öğretmen adayından 24 tanesi, fiziksel aktiviteye katlımda aile faktörünün önemine vurgu yapmıştr. 15 öğretmen adayı ailenin olumlu etkisine vurgu yaparken, 9 öğretmen adayı da fiziksel aktiviteye katılımda ailenin olumsuz etkisinden bahsetmiştir. Erken yaşlarda bir spor branşına yönlendirme ve aile üyelerinden en az birinin (anne, baba, kardeş) fiziksel aktiviteye katılımı ailenin olumlu etkileri olarak vurgulanmıştir:

"Babamın profesyonel voleybolcu olması, benim ve kız kardeşimin de bu spora yönelmemizde büyük katkısı olmuştur" (ÖA16).

"Ailem, özellikle de annem, erken yaşlarda karateye gitmem konusunda beni desteklemişti ve bu konuda çok şanslı olduğumu düşünüyorum" (ÖA6).

"Babam polis ve şu an bile fiziksel olarak çok aktif birisi. Annem haftada en az 2 kere pilates yapar. Çocukluğumdan beri spora hep ilgim olmuştur. Illkokula giderken yüzme ve tenis kurslarına gitmiştim" (ÖA3).

"Babam benim rol modelimdi. Her sabah mutlaka ya koşmaya ya da yürüyüşe çıkardı. Beden eğitimi öğretmeni olmamasına rağmen, okuldaki diğer öğretmen arkadaşlarıyla basketbol oynardı. Bütün bunlar benim fiziksel aktiviteye bakış açımı etkilemiştir ve ilkokul yıllarında okulun basketbol takımına girmiştim" (ÖA8).

Öğretmen adayları ( $n=9)$, ailenin fiziksel aktiviteye bakış açısı, ailede kilo problemi olması, ailenin sınav sistemi kaygısı ve yoğun iş temposu gibi faktörlerin fiziksel aktiviteye katlımlarında olumsuz etkisi olduğunu vurgulamışlardır:

"Ailemin hiçbir spor aktivitesine ilgisi yoktu. Geçmişlerinde de herhangi bir spor deneyimleri olmamış. Ayrı$c a$, bütün aile bireylerinde kilo problemi ve düzensiz yemek yeme alışkanlığı var. Ben hiçbir zaman herhangi bir spor aktivitesine katılmadım. Şu an kilo benim de problemim var ve bu beni yetersiz ve sürekli yorgun yapıyor" (ÖA14).

"Annem fiziksel aktiviteye kathlımım için beni her zaman desteklemişti ama babamın olumsuz tepkileri kar- 
şısında vaktimi genelde evde koşturarak ya da dans ederek geçirmiştim. 6 yaşında baleye gitmek istediğimi söylediğimde babam artk çok geç olduğunu söylemişti. 9 yaşında okulun seçmeli derslerinden yüzmeyi seçmiştim ama babamın izni olmadan devam etmek zorunda kalmıştım" (ÖA26).

"Amcam voleybol oynamam konusunda beni desteklemişti ve okulun voleybol takımına girmiştim. Uzun zaman oynadım ama lisede üniversite sınavlarına hazırlanmak zorunda olmam, ailemin voleybolu bırakmam konusunda bana baskı yapmasına sebep oldu ben de bıraktım" (ÖA4).

Katılımcı 28 öğretmen adayından 22 tanesi aynı zamanda fiziksel aktiviteye katlımda öğretmen faktörünün önemine de vurgu yapmıştr. Aile faktörünün aksine, katlımcıların çoğunluğu $(n=17)$, beden eğitimi ya da spor branş öğretmenlerinin fiziksel aktiviteye katılımlarını olumsuz etkilediklerini belirtmiştir. Sadece 5 katılımcı, öğretmen faktörünün olumlu etkisinden bahsetmiştir:

"Okullarımdaki beden eğitimi öğretmenleri beni olumsuz etkilemişlerdir. Beden eğitimi dersleri rahatlayacağımız ve serbestçe hareket edebileceğimiz tek seçenekken bunun avantajını hiçbir zaman yaşayamadım. Derslerde sürekli sağa sola dön, ileri geri yürü gibi yönergeleri hatırlıyorum. Bu da benim sıkılmama ve beden eğitiminden nefret etmeme sebep oldu" (ÖA22).

"Beden eğitimi derslerini hayatım boyunca sıkıcı buldum. Sürekli tekrarlardan ibaret hareketler, öğretmenin dur, hazır ol, sağa dön, sola dön gibi yönergeleri beni spordan soğuttu" (ÖA7).

"Beden eğitimi öğretmenleri öğrencileri spora katılım konusunda iyi motive edemiyorlar. Sınıfta genelde herkes voleybol oynardı ama ben oynamak istemezdim çünkü iyi değildim. Ama iyi bir sebebimiz yoksa hepimiz oynamak zorundaydık ve bu benim beden eğitimi dersinden nefret etmememe sebep oldu" (ÖA9).

"Basketbol ve voleybol beden eğitimi dersinin zorunlulukları arasındaydı. Her ders oynamak zorundaydık ve ben istemiyordum. Bu da beni her ders strese sokuyordu ve zaman içerisinde kendime güven sorunum başladı" (ÖA24).

"Çocukluğumdan beri fiziksel aktivitelere katılmaktan korkmuşumdur. Beden eğitimi öğretmenlerim hiç tolerans göstermezlerdi ve en ufak bir şey olduğunda hepimize kızarlardı. Onların sayesinde şu an hala çekincelerim var" (ÖA14).

Beden eğitimi derslerinde kullanılan öğretim yöntemlerinin ve öğretmen tutumlarının öğretmen adaylarının fiziksel aktiviteye katlımlarında olumsuz bir etkiye sebep olduğu görülmektedir. Öte yandan, az sayıda $(n=5)$ katlımcı beden eğitimi öğretmenlerinin motive edici olduğunu ve şu anki fiziksel aktivite katılımlarında belirleyici rol oynadığını vurgulamıştır. Son olarak, katlımcı 28 öğretmen adayından 12 tanesi arkadaş faktörünün de fiziksel aktiviteye katlımda önemli rol bir oynadığını belirtmiştir. Ayrıca, 11 katlımcı, bu faktörün olumlu anlamda etkisinden bahsetmiştir. Sadece 1 tanesi olumsuz olarak etkilediğini söylemiştir.

\section{Çevresel faktörlerin fiziksel aktivite katılımına etkisi}

Katılımcı öğretmen adaylarının hepsi $(n=28)$ spor salonlarına ve faaliyetlerine erişimin fiziksel aktiviteye katılımda önemli bir yere sahip olduğunu belirtmiştir. Ayrıca, okulda sunulan spor olanaklarının da $(n=18)$ katılım için gerekli olduğu vurgulanmışttr. Katlımcıların büyük çoğunluğu $(n=24)$, eğitim gördükleri okullarda sunulan spor imkanlarının yetersizliğinden bahsetmiştir:

"Hem ilköğretim hem de lise eğitimim boyunca okuduğum okullarda fiziksel aktiviteyi destekleyecek herhangi bir olanak yoktu. Sadece bir tane basketbol potası vardı" (ÖA21).

"Beden eğitimi derslerinde birkaç top dışında çok fazla materyalimiz yoktu. Sadece okul takımında olan ve turnuvaya hazırlanan öğrencilerin kullanımına açık olan bir spor salonu vardı, her zaman kullanamazdık" (ÖA23).

"ilkokulda kızların katılabileceği herhangi bir spor yoktu. Çoğunlukla, erkeklerin olduğu futbol ve basketbol takımları vardı ve bana uygun olduğunu düşünmüyordum" (ÖA6).

"Okulda cimnastik salonu olmadığından kış mevsimlerinde beden eğitimi dersi yapmıyorduk" (ÖA7).

"Futbol ya da basketbol sahamız yoktu. Sadece bir tane oyun oynadığımız alan vardı ama onu da yıkmışlardı. Zamanımız falan olmadığından değil, oynayacak yerimiz olmadığından spor etkinliklerine katılamıyorduk" (ÖA12).

Sınırlı fiziksel aktivite olanaklarından bahseden katılımcıların çoğunluğu, eğitim gördükleri üniversitenin kendilerine sunduğu fiziksel aktivitelerden yararlanmaya çalıştklarını belirtmiştir. Ayrıca, üniversite bünyesinde, fiziksel aktiviteye katılımı özendirecek pek çok spor kulübünün ve faaliyetinin olması katlımcılar $(n=18)$ tarafindan fiziksel aktiviteye başlama motivasyonu olarak vurgulanmıştir. 
"Üniversiteye geldiğimden beri pek çok spor aktivitesine katılma firsatım oldu.Uzun bir süre zumba yaptım ve tenis dersleri aldım. Yoga, pilates ve yüzme dersleri de aldım. Son olarak da cankurtarma ve ilkyardım kulübüne girerek eğitimlerini aldım" (ÖA9).

"Üniversitem bana pek çok spor olanağı sunuyor. Kürek takımına katıldım. Zumba ve fitness derslerine başladım. İstediğim zaman okulun stadyumuna gidip koşabiliyorum. Ayrıca, okulda birden fazla spor salonu var ve istediğiniz zaman gidip çalışabiliyorsunuz. Ne kadar aktif olursam, derslerime de o kadar odaklanabildiğimi fark ettim ve bu ortalamama da yansıdı" (ÖA26).

"Üniversitede fiziksel aktivite anlamında çok fazla seçeneğimiz var. Spor salonlarının, yüzme havuzlarının ve koşmak için alanların olması en önemli motivasyon kaynaklarım" (ÖA28).

"Spora katılma açısından kampüs çok fazla seçenek sunuyor ve değişik sporları deneme firsatınız oluyor, eskrim, pilates ve yoga gibi. Şu an hala yoga yapıyorum ve kendimi daha iyi ve güçlü hissediyorum" (ÖA11).

"Okul hayatım boyunca herhangi bir spora ya da spor takımına katılmadım. Okuduğum okullarda spor salonu hatta oyun alanı bile yoktu. Ama şimdi üniversitenin sunduğu çok fazla imkan var. Haftada 2 kere pilates yapıyorum ve bu beni sağlıklı ve mutlu yapıyor" (ÖA3).

\section{Öğretmenlik Uygulamalarında Fiziksel Aktivite Etkisi}

Katılımcıların çoğunluğu, fiziksel aktiviteye katılımın kendilerini daha sağı|ılı, mutlu ve başarılı yaptığını vurgularken, öğretmen olduklarında sınıflarında fiziksel aktivitelere yer vermek istediklerini fakat kendi fiziksel yeterlilikleriyle ilgili tedirginlikleri olduğunu dile getirmişlerdir. Bu sebeple, fiziksel aktiviteleri doğrudan öğretmek yerine herhangi bir kavram ya da konu öğretiminde araç olarak kullanarak sınıf içine entegre edebileceklerini belirtmişlerdir.

"Öğretmen olduğumda öğrencilerimin benim maruz kaldığım sıkıı beden eğitimi derslerine maruz kalmasını istemem. Çocuklara fen ya da matematikle ilgili bir şey öğretirken dansı, aktif oyunları, ya da müziği kullanırım.Öğrencilerimle birlikte sınıfta koşar ya da zıplarım. Onların hareket ederken hem eğleneceği hem öğreneceği aktif oyunlar hazırlarım" (ÖA26).

"Fiziksel aktivitenin çocuklar için ne kadar önemli olduğunu biliyorum. Öğretmen olduğumda kendimde fiziksel aktiviteleri öğretecek yeterliliği bulmuyorum ama benim çocukluğumun aksine öğrencilerimi fiziksel aktivitelere katlımları konusunda motive edebileceğimi ve destekleyebileceğimi biliyorum" (ÖA3).

"Fiziksel aktivite konusunda yeterince deneyimim olmadığımdan çocuklara öğretme konusunda epeyce tedirginliklerim var. Yanlış birşey öğretmek ya da yanlış bir tutum sergileyip onların da fiziksel aktiviteye karşı olumsuz bir yaklaşım geliştirmelerini istemem" (ÖA11).

"Aktif bir yaşam tarzım olmadığının ama okul öncesi öğretmeni olarak sınıfta aktif olmam gerektiğinin farkındayım. Geçmiş okul deneyimlerim beden eğitimine yaklaşımımı olumsuz etkiledi ama öğretmen olduğumda bunu değiştirmek istiyorum. Benim kaçırdığım firsatları onların da kaçırmasını istemem" (ÖA6).

Katılımcı öğretmen adaylarının çoğunluğu $(n=25)$, kendi fiziksel becerilerini geliştirebilecekleri hizmet-içi eğitimler yoluyla sınıf içerisinde hareketi ya da fiziksel aktiviteleri daha rahat kullanacaklarını vurgulamıştır. Katılımcılar, öğretmen olduklarında sınıf-içi etkinlik geçişlerinde, sınıf kontrolünü sağlamada, çocukların ilgisini ve dikkatini çekmede ve öğrenmenin aktif ve eğlenceli olmasında hareketi kullanabileceklerini belirtmişlerdir. Bununla beraber, sınıfin fiziksel şartları, okul yöneticisinin tutumu, ailelerin konuya bakış açısı ve günlük/haftalık planda beden eğitimine ayrılan ders saati katlımcılar tarafindan amaçlarına ulaşmada düşünülmesi gereken noktalar olarak vurgulanmıştır.

\section{Tartışma}

Öğretmen adaylarının fiziksel aktiviteye katılımlarında etkili olan faktörlerin neler olduğu sorusunun arandığı araştırmada, katılımcıların bireysel hikayelerini içeren otobiyografik anlatımlarından elde edilen sonuçlara göre aile ve sosyal çevre ile çevresel faktörlerin önemli bir rol oynadığı ve bu deneyimlerin ileriki öğretmenlik uygulamalarına da yansıyabileceği ortaya çıkmıştı. Özellikle, fiziksel aktiviteye katlıımda aile faktörünün hem olumlu hem de olumsuz etkisinden bahsedilirken, katılımcıların çoğunluğu öğretmen faktörünün olumsuz etkisinden bahsetmiştir. Bunlara ek olarak, bütün katlımcılar spor salonlarına ve faaliyetlerine erişimin fiziksel aktiviteye katlımda önemli olduğunu belirtmiştir. Okullarda sunulan spor olanaklarının yetersizliğinden bahseden katılımcıların çoğunluğu, eğitim gördükleri üniversitenin sunduğu imkanlarla fiziksel aktivite intiyaçlarını kolaylıkla karşılayabildiklerini belirtmiştir.

Fiziksel aktiviteye katılımda aile ve sosyal çevre faktörlerinin etkisi ulusal ve uluslararası alan yazınında sıklıkla vurgulanmaktadır. Çalışmanın sonuçları ile paralel olarak, King, Tergerson, ve Wilson (2008) yaptı̆̆ı araştırmada, fiziksel aktiviteye kathlımda aile ve arkadaş desteği alan kişilerin daha aktif bir yaşam biçimi sürdükleri ortaya çıkmıştır. Katılımcı 
öğretmen adaylarının otobiyografik anlatımlarında da belirtildiği gibi, aile bireylerinden en az birinin sporla ilgilenmesi fiziksel aktiviteye kathlımlarını olumlu yönde etkilemiştir. Benzer şekilde, Alemdağ ve Öncü (2015), ailesinde sporla ilgilenen öğretmen adaylarının fiziksel aktiviteye katılımda daha etkin rol oynadıklarını tespit etmiştir. Öte yandan, katılımcıların bir kısmı, çeşitli sebeplerden dolayı aile desteğini yeterince alamadıklarını belirtmiştir. Benzer bulgular, Bentley vd., (2012) ile Kahn vd. (2008) tarafindan yapılan araştırmalarda da ortaya çıkmış ve fiziksel aktiviteye katılım konusunda ailelerin farkındalığııı arttrılması gerektiği vurgulanmıştır. Ayrıca, Anderson, Hughes, ve Fuemmeler (2009) yaptıkları çalışmada, ailenin destekleyici bir rolde olmasının, çocukların düzenli spor yapma ve spora karşı olumlu tutum sergilemelerinde etkili olduğunu ortaya koymuştur.

Fiziksel aktivite alışkanlığının yaşam boyu sürdürülmesinde aile desteğinin yanı sıra, beden eğitimi öğretmeni tarafindan verilen destek ve motivasyon da belirleyici önem taşımaktadır. Çalışmaya katılan öğretmen adaylarının çoğunluğu, fiziksel aktiviteye katlımda beden eğitimi öğretmeninin olumsuz etkisinden bahsetmiştir. Özellikle, derslerin işleyiş biçiminden kaynaklanan problemlerden dolayı beden eğitimi dersine karşı olumsuz tutum sergilediklerini ortaya çıkartmaktadır. Benzer bulgular, Yüksel ve Tuncel (2017) tarafindan yapılan araştrmada da ortaya çıkmış ve çalışmaya katılan öğretmen adayları geçmiş beden eğitimi deneyimlerinden genellikle olumsuz olarak bahsetmiştir. Aynı şekilde, Xiang, Lowy ve Mcbride'in (2002) çalışmasında, sınıf öğretmeni adaylarından beden eğitimi dersinin öğretimine karşı olumsuz tutum gösterenlerin geçmiş deneyimlerinin de olumsuz olduğu ortaya çıkmıştr.

Çalışmadan elde edilen diğer bulgular, spor salonlarına ve faaliyetlerine erişimin fiziksel aktiviteye katılımda önemli bir rol oynadığını gösterirken, öğretmen adaylarının çoğunluğunun geçmiş okul yaşantılarında bu tür olanaklara sahip olmadıklarını göstermektedir. Pek çok ulusal ve uluslararası alan yazınında spor salonuna erişim olanaklarının bireylerin fiziksel aktiviteye katıımlarını olumlu yönde etkilediği vurgulanmaktadır. Cengiz ve İnce (2013), ilköğretim ikinci kademe öğrencilerinin okul sonrası fiziksel aktivite öz-yeterlik, personel ve ebeveyn etkisi algılarını okul çevresi ve cinsiyet değişkenlerine göre inceledikleri çalışmalarında destekleyici fiziksel ve sosyal çevrenin çocukların okul sonrası fiziksel aktivite öz-yeterlik değerlerinin yüksek olmasında etkili olduğunu bulmuştur. Benzer şekilde, Lee vd. (2016) spor saIonlarına kolay erişimi olan bireylerin, olmayanlara oranla daha fazla fiziksel aktiviteye katıldıklarını ortaya çıkarmıştır. Öğretmen adaylarının otobiyografik anlatımlarında da benzer sonuçlar çıkmıştır. Geçmiş okul yaşantılarında spor saIonlarına ve faaliyetlerine erişimi olmayan pek çok katılımcı, öğrenim gördükleri üniversitenin sunduğu fiziksel aktivite imkanlardan dolayı spor ve fiziksel aktivelere düzenli olarak katıldıklarını belirtmiştir.

Fiziksel aktiviteye katılımda etkili olduğu vurgulanan tüm bu faktörlerin katlımcıların öğretmen olduklarında sınıf uygulamalarına da yansıyabileceği ortaya çıkmaktadır. Katılımcıların çoğunluğu, fiziksel aktivitenin çocuklar için öneminden bahsederken, öğretmen olduklarında destekleyici bir rolde olacaklarını fakat fiziksel öz-yeterliklerinden kaynaklı tedirginlikleri olduğunu vurgulamışlardır. Bu sebeple, fiziksel aktivite ya da hareketi daha çok kavram öğretiminde ya da aktivite geçişlerinde araç olarak kullanacaklarını söylemişlerdir. Çalışmanın bulguları Alemdağ, Öncü, ve Sakallıoğlu (2014) tarafindan yapılan araştırmanın sonuçlarıyla benzerlik göstermektedir. Araştırmacılar, düzenli olarak spor yapan sınıf öğretmeni adaylarının beden eğitimi dersine karşı tutumlarını ve dersin öğretimine yönelik öz-yeterliklerini anlamlı bir şekilde daha yüksek olduğunu bulmuştur. Benzer şekilde, geçmişte olumsuz beden eğitimi deneyimine sahip sınıf öğretmeni adaylarının fiziksel aktiviteye katılımlarının düşük olmasının yanı sıra, beden eğitimi dersini öğretme konusunda düşük öz-yeterliklere sahip olduğu ortaya çıkmıştır (Morgan \& Bourke, 2008).

\section{Sonuç ve öneriler}

Bireylerin fiziksel aktiviteye katılımlarında belirleyici rol oynayan aile farkındalığının arttırılması büyük önem taşımaktadır. Özellikle, erken çocukluk döneminde edinilen temel hareket becerileri, bireylerin aktif bir yaşam biçimi benimsemesinde etkili olmaktadır. Bu sebeple, aile beklentilerinin anlaşılıp temel hareket becerilerinin geliştirilmesi konusunda aile seminerleri ya da ailelerle etkileşimli uygulamalar yoluyla farkındalığın arttırılması sağlanabilir. Ayrıca, ailenin fiziksel aktiviteye katılımının, bu konudaki tutumlarının ve fiziksel aktivite bilgi düzeylerinin öğrenilmesi farkındalıklarının arttırımasında izlenecek yollara ışık tutacaktır. Aile faktörünün yanı sıra, beden eğitimi okul deneyimleri de fiziksel aktiviteye katılımda büyük bir öneme sahip. Beden eğitimi derslerinin daha çok çocuk merkezli, süreç odaklı, işbirliğini özendiren ve yaratıcılığı destekleyen nitelikte uygulamalar içermesi, çocukların fiziksel aktiviteyi yaşam boyu sürdürebilecekleri bir alışkanlık olarak görmelerini sağlayacaktır. Bunlara ek olarak, erken çocukluk döneminde hareket eğitiminin desteklenmesinde öğretmenin fiziksel öz-yeterlik düzeyi ve konuyla ilgili pedagojik bilgi birikimi önem taşımaktadır. Bu sebeple, öğretmen adaylarını hem kendi fiziksel becerilerini geliştirebilecekleri hem de beden eğitimi öğretiminde gerekli teorik ve pratik bilgi altyapısının verildiği uygulama ağırlıklı seçmeli derslere yönlendirmek faydalı olacaktır. Ayrıca, okulların iç ve dış mekan fiziksel alt yapılarının ve malzeme ihtiyacının gözden geçirilip temel hareket becerilerini destekleyecek şekilde düzenlenmesi gerekmektedir. Okul öncesi eğitim kurumları hareket becerilerinin 
desteklenmesi için uygun ortamlar sunma konusunda ilk ve ortaöğretim kademelerine göre daha esnek olabilmektedir. Fakat, ulusal ve uluslararası alan yazında yetersiz fiziksel koşullar okul öncesi dönemde hareket eğitiminin uygulanmasında karşılaşılan en büyük engeller arasında gösterilmektedir. Bu sebeple, sınıf ortamlarının hareketi destekleyecek aktif tasarımlara yönelmesi ve hareketin diğer konu ve kavramlara entegre edilerek öğrenmenin aktifleştirilmesi gerekmektedir. Son olarak, yukarıda bahsedilen faktörlerin bireylerin aktif bir yaşam benimsemesinde etkili olmasının yanı sıra öğretmenlik uygulamalarını da belirleyici derecede etkilediğini göz önünde bulundurarak okullardaki beden eğitimi ve spor derslerinin içerik ve işleyişinin dikkatli bir şekilde gözden geçirilmesi gerekmektedir.

\section{Kaynakça}

Alan, B. (2016). Öğretmen eğitiminde nitel bir araştırma yöntemi olarak bireysel araştırma. Eğitimde Nitel Araşttrmalar Dergisi, $4(1), 7-25$.

Alemdağ, S., \& Öncü, E. (2015). The investigation of participation physical activity and social appearance anxiety at the preservice teachers. International Journal of Science Culture and Sport, 3, 278-300.

Alemdağ, S., Öncü, E., \& Sakallığlu, F. (2014). Sınıf öğretmeni adaylarının beden eğitimi dersine yönelik tutum ve öz-yeterlikleri. Abant İzet Baysal Üniversitesi Eğitim Fakültesi Dergisi, 14(2), 45-60.

Anderson, C.B., Hughes, S.O., \& Fuemmeler, B.F. (2009). Parent-child attitude congruence on type and intensity of physical activity: testing multiple mediators of sedentary behavior in older children. Health Psychology, 28(4), 428-438.

Bentley, G. F., Goodred, J. K., Jago, R., Sebire, S. J., Lucas, P. J., Fox, K. R., ... \& Turner, K. M. (2012). Parents' views on child physical activity and their implications for physical activity parenting interventions: a qualitative study. BMC pediatrics, 12(1), 180.

Bower, J. K., Hales, D. P., Tate, D. F., Rubin, D. A., Benjamin, S. E., \& Ward, D. S. (2008). The childcare environment and children's physical activity. American Journal of Preventive Medicine, 34, 23-29.

Brady, L., Gibb, J., Henshall, A., \& Lewis, J. (2008). Play and exercise in early years: physically active play in early childhood provision. London: Department for Culture, Media and Sport.

Cashmore, A.W., \& Sandra, J.C. (2008). Growing up active: a study into physical activity in long day care centres. Journal of Research in Childhood Education, 23, 179-191.

Cengiz, C., \& Ince, M. L. (2013). Farklı okul ortamlarındaki çocukların okul sonrası fiziksel aktivitelerde algıladıkları öz-yeterlilikleri. Yönetim Bilimleri Dergisi 11(21), 135-147.

Copeland, K.A., Kendeigh, C.A., Saelens, B.E., Kalkwarf, H.J., \& Sherman, S.N. (2012). Physical activity in child-care centers: do teachers hold the key to the playground? Health Education Research, 27, 81-100.

Dowda, M., Brown, W.H., Mclver, K.L., Pfeiffer, K.A., O’Neill, J.R., Addy, C.L., \& Pate, R. R. (2009). Policies and characteristics of the preschool environment and physical activity of young children. Pediatrics, 123, 261-266.

Gabbard, C. (2000). Lifelong motor development. Champaign, IL: Human Kinetics.

Gallahue, D., \& Ozmun, J. (1998). Understanding motor development infants, children, adolescents, adults. New York: McGraw-Hill.

Graham, G., Fraser, R., Parker, S., Tembo, M., Westfall, S., \& Wilkins, J.M. (2002). The effect of high stakes testing on elementary school art, music and physical education. The Journal of Physical Education, Recreation \& Dance, 73, 8, 51-54.

Huang, J.S., Sallis, J., \& Patrick, K. (2009). The role of primary care in promoting children's physical activity. Journal of Sports Medicine, 43, 19-21.

Ignico, A. (1994). Early childhood physical education: providing the foundation. Journal of Physical Education, Recreation and Dance, 65, 28-30.

Kahn, J. A., Huang, B., Gillman, M.W., Field, A. E., Austin, S. B., Colditz, G. A, \& Frazier, A.L. (2008). Patterns and determinants of physical activity in U.S. adolescents. Journal of Adolescent Health, 42, 369-377.

King, K.A., Tergerson, J.L. \& Wilson, B.R. (2008). Effect of social support on adolescents' perceptions of and engagement in physical activity. Journal of Physical Activity and Health, 5(3), 374-384.

Lee, S. A., Ju, Y. J., Lee, J. E., Hyun, I. S., Nam, J. Y., Han, K. T., \& Park, E. C. (2016). The relationship between sports facility accessibility and physical activity among Korean adults. BMC Public Health, 16, 1-8.

Morgan, P., \& Bourke, S. (2008). Non-specialist teachers' confidence to teach PE: the nature and influence of personal school experiences in PE. Physical Education and Sport Pedagogy, 13(1), 1-29. 